\title{
State Response to Contemporary Urban Movements in Turkey: A Critical Overview of State Entrepreneurialism and Authoritarian Interventions
}

\author{
Ayda Eraydin \\ Department of City and Regional Planning, Middle East Technical University, Ankara, Turkey; \\ ayda@metu.edu.tr
}

\section{Tuna Tașan-Kok}

OTB Research Institute for the Built Environment, Delft University of Technology, Delft, The Netherlands; m.t.tasan-kok@tudelft.nl

\begin{abstract}
This paper grapples with the state's response to contemporary urban movements. In light of recent debates on the changing nature of urban movements, it presents an overview of the responses of states in different modes of regulation, ranging from a Keynesian regime to sequential stages of neoliberalisation. Examples of authoritarianism and the entrepreneurial roles of the state are drawn from the Turkish experience to show how economic liberalism can be combined with increasing social control, restrictions, penalisation and exclusion. Reviewing Turkish urban policies and practice, the urban mobilisations against them, and the varying positions of the state will shed light not only on what is happening in Turkey but also on the transformative nature of neoliberalisation.
\end{abstract}

Keywords: urban movements, state entrepreneurialism, authoritarian interventions, neoliberalisation

\section{Introduction}

The context of urban movements has changed substantially since the 2000s, and so has the state's response. The literature provides insight into new policies and practices that induced the contemporary urban movements: the state's increasing interest in urban regulation and the commodification of urban land in order to finance economic growth (Peck et al., 2009); the increasing influence of state entrepreneurialism on urban management (MacLeod 2002); the engagement of the governance regime in making policy, controlling, and articulating the requirements of a global neoliberal market economy (Brenner et al., 2010; Hilgers 2012; Peck et al., 2009; Wacquant 2012). This literature also emphasises the strong involvement of the economic, political, and cultural elites in governance arrangements (Swyngedouw 2010), excluding others from the configuration of state-market-citizen relations (MacLeod 2002; van Eijk 2010; Wacquant 2012). Although there are various studies on the new roles of the state that aim to 
pacify opponents to neoliberal urban management with authoritarian and entrepreneurial state interventions (Piffero 2009; Swyngedouw 2010; Zunino 2006) or the ambidextrous relationships between the authoritarian and the assistential wings of the state (Peck 2010), two issues do not receive enough attention. The first is urban policy and practice as a means of transforming the socio-political characteristics of society. The second is the emergence of new partnerships between the state, the market, and the citizens, which not only disregard the aspirations of others but place restrictive measures on them.

This paper underlines three dynamics that may offer new insights into the debate on the state's response to urban social movements in Turkey. First, the response of the Turkish state to urban movements in the last decade illustrates that economic neoliberalism does not have to coincide with the dismantling of the state. Instead, neoliberalism re-uses the state in the interests of the market order, as elaborated by several authors (see Hilgers 2012; Peck 2010; Wacquant 2012). Neoliberal urban policies and practice are used to legitimise the enhancement of authoritarian governance. Second, it shows that governments use urban areas not only as a growth machine ${ }^{1}$ but also as grounds for a socio-political transformation project. This approach, which necessitated a strong role for the state, has engendered different forms of intervention in urban areas combining economic neoliberalism with increasing social control, restrictions, penalisation, and exclusion of certain social groups. Third, the response of the Turkish state to urban movements depicts changing partnerships between the state, the market, and the citizens. Contrary to debates on the strong role of cultural elites in governance arrangements, the paper points to increasing exclusion of former elites, ${ }^{2}$ disadvantaged groups, and minorities in favour of the newly emerging socially conservative, economically liberal groups known as conservative elites in Turkey (Yılmaz 2009). That explains the very recent urban movement composed of different groups that feel their lifestyles and quality of life have been deeply threatened by these policies. This paper explores the roots of contemporary urban movements consisting of young intellectuals, leftist groups, socialist Muslims, liberals, and many others who are united against what is going on in Turkey's major cities.

After sketching the contours of urban policies and practice in Turkey, the paper describes some urban mobilisations and the varying positions taken by the state in response. The subsequent analysis sets the stage for a discussion of changing state response in the case of Turkey. At another level, it may contribute to the general understanding of transforming contemporary neoliberalisation. It covers the urban agenda of the state, emerging contestations to urban practices, and the state's attitude to urban movements over the last decade or so, drawing upon micro and macro urban political-economic and institutional analysis. The paper is organised as follows. The section after this introduction reviews the recent debate on urban movements and government attitudes towards them. The third section depicts Turkey's urban movements and urban agendas in three different periods. The fourth elaborates on the state's responses to these movements. A critical evaluation of trends in state entrepreneurialism and authoritarian governance concludes the paper. 


\section{Changing Nature of Urban Movements and Response of the State}

The literature on the causes and character of urban movements and the response of the state provides theoretical debates and empirical material, combined with evidence to explain the geographical variation and different pathways in different contexts (Walton 1998). In view of the common features of the state's response to urban movements, three different types of state response can be identified since the 1960s: collective consumption, urban social movements, and clientelism (ie the urban politics of the post-war period for many places); the new entrepreneurialism (a first strand of revision of post-war urban politics); and the new authoritarianism (a second strand of revision of post-war urban politics, connected to the first strand). Over that period, changes in the attitude of states towards urban social movements have shown a clear pattern. Since these categories are artificial, there may be exceptions and overlaps in the real world of politics. Nonetheless, this typology offers insight by illustrating that states deploy similar strategies to suppress urban social movements, especially when the latter make similar requests for rights to the city.

The first type includes clientelist policies as a response to urban social movements organised around collective consumption. The clientelist tendencies in policy and practice is seen in many geographies as a response to urban movements that were inspired by the desire for access to collective consumption goods and the demand for better living conditions that was nurtured by the crisis in Atlantic Fordism (Jessop 2002) in the 1960s and 1970s. These movements called for a structural transformation of the urban system to allow for participation and protest (Castells 1977); all were buoyed up by a wave of activism along the fronts of collective consumption (Mayer 2007). In the same period, in most of the Third World, where "developmental" strategies were followed for economic growth (Walton 1998), civil society was questioning the liveability of cities and pushing for political reform due to the urban bias created by the disproportional public investment in big cities (Douglas 2003). In the background, some countries (eg in the southern cone of Latin America and in Southern Europe) went through a difficult process of political liberation, on the one hand, and civil and military coups, fraud, and authoritarian backlash, on the other (Rocha 2012). In general, government responses were not forthright, since the activists were calling for radical changes-for instance, they wanted the cities to be organised according to use value. They also rallied against the cultural norms of institutions and for collective consumption goods for all. But such deep reforms were unattainable at the time due to the financial problems exposed during the economic crisis of the 1970s. Instead, the demands for more urban services, collective consumption, and the transfer of property rights encouraged some clientelist tendencies in policy and practice. The informalities associated with such populism became embedded in the mode of governance that was ubiquitous in the 1960s and 1970s. The patron-client relations formed between the immigrant urban poor and the local and central states have been well documented in many developing countries in this period (Castells 1983; Walton 1998). Turkey was no exception. 
A second type can be defined around the new entrepreneurialism, as a first strand of revision of post-war urban politics after the 1970s crisis. In this period, the state's response to urban social movements has two distinctive characteristics. First of all, innovative and participatory governance approaches are developed by central governments in response to urban contestations. The state becomes more entrepreneurial and tries to turn contestations into a controlled involvement of social groups. Second, inspired by the increasing opportunities provided by the property markets, the state responded to the contestations with institutional restructuring and re-regulation on property markets.

The innovative and participatory governance approaches were triggered by the economic dynamics eroding the social welfare state and thereby generating unemployment, poverty and social deprivation at the beginning of the 1980s. In the Western world, the legacy of Thatcher and Reagan inspired a diminishing welfare state; unemployment was deemed acceptable, deregulation became common practice, and workers' claims for better living standards and working conditions were repressed (Dumenil and Levy 2009). The outcomes on the city were drastic. For instance, the privatisation of social housing in Britain created a rent and price structure throughout metropolitan London that has prevented lower- and even middle-income groups from accessing accommodation near the city centre (Harvey 2008). The cities in shielded economies of developmental states, socialist countries, and other parts of the Third World have undergone similar though slower transformations, but an increase in poverty and social deprivation became common. Massive mobilisations were experienced in cities, both in welfare states and in the developing world, though for different reasons. These took the form of squatting and invasion as means to gain access to affordable housing (Holm and Kuhn 2011). Both squatting and invasion movements, as Leontidou (2010) illustrates in Southern European cases, eventually melded with grassroots petitions for participation in elected institutions of municipalities and an active role in political decision-making.

The responses to these changes in the 1980s have been compiled in the literature and subsumed under several headings. These are concepts with broad currency in the discourse on urban dissent and mobilisation: "participation", "governance beyond the state", "governing ourselves", etc. As Mayer (2009:364) notes, "this was a period of reconfiguration in the relations between urban movements and municipalities". Shifting from the clientelist and populist policies of an earlier period, local authorities introduced innovative forms of governance. Co-operative actions revolved around "participation", which became common practice around the world in the 1980s in a variety of forms and at different speeds. Over time, "a transition from urban social movements challenging the state to a less oppositional relationship between 'interest groups' and a local (welfare) bureaucracy ... occurred" (Mayer 2000:136). The projects introduced in this period enabled the people involved in urban movements to professionalise and thereby participate in local bargaining processes. However, the ensuing change in society was limited under the participation approach (Blakeley 2010). Nonetheless, the participatory activities did have an impact: they sapped the strength of the urban movements, with the exception of those organised by people who had not found a place in these participatory practices. 
The tendency for institutional restructuring and re-regulation on property markets was a response to social mobilisations that were ignited by a competitiveness agenda, epitomised by third-way policies. This roll-out neoliberalism evinces new forms of institution building and government intervention (Peck and Tickell 2002). It created new opportunity spaces, social sites, and vehicles for inducing new types of liaisons between government and diverse social groups. In the developing world, as Walton (1998) notes, despite the variety of national responses to changing global economic conditions, there was a general increase in labour disputes and austerity protests during the years of economic recession. In some Latin American countries, social mobilisations included direct action (eg roadblocks in Argentina) by workers attempting to gain some control over income benefits (Feliz, 2012). In some other countries, municipalities sponsored indirect participatory action-in Brazil, for instance, communities were forced to have elected representatives-to prevent bottom-up social mobilisations.

In the Western world, the "right-to-the-city" discourse has been back on the agenda from the 1990s on, though in a context unlike that of Lefebvre's radical and oppositional notion. Further, the "resistance to accumulation by dispossession" (Harvey 2003) ${ }^{3}$ has been picked up by "new" social movements concerned with issues such as land and minority rights (Hickey and Bracking 2005). In this period, socially ameliorative interventions were aimed at providing a certain degree of collective consumption and at upgrading the living spaces of the disadvantaged. Meanwhile, the terrain of profitable activities was expanded with the help of policies and plans. Citizens and interest groups have become stakeholders in this increasingly fragmented and participatory governance system. Concomitantly, social mobilisations became part of an organised and formalised negotiation process. However, the new mechanisms did not include certain social groups or even allow their interests to be represented in the decision-making system. Institutional restructuring and property market re-regulation was a deliberate strategy to pacify those opposing the new competitive urban politics as well as those acting against the erosion of the welfare state (Kratke 1992, 2004).

Finally, it is possible to identify a third type that comprises policies that aim to pacify the opponents to neoliberal urban management with authoritarian and entrepreneurial state interventions, a tendency that emerged over the past decade. This tendency, as a second strand of change to post-war urban politics, can be described as new authoritarianism. The evidence from certain countries suggests that neoliberal urban restructuring often involves new forms of authoritarianism based on the wearing down of democratic control and the selective limitation of citizenship rights in common ways (Baptista 2012; Smith 2002; Swyngedouw 1996). Despite their diverse intellectual groundings, these observations illustrate that states deploy legal practices of exception to delineate new spaces of rule (Baptista 2012:40).

The urban policies and practices with a neoliberal approach to urban management provoked opposition, which in some cases has spawned urban movements. They opposed not only current urban practices but also some less concrete trends: the commodification of urban space, socio-spatial segmentation, and gentrification, among others (Leitner et al. 2007). Besides, the voices of the deprived have risen to a clamour. Their activism was focused on defending the rights of individuals 
in projects initiated and supported by the state. Their protests were mainly expressions of dissatisfaction with state interventions. The notion of urban revanchism sums up the concerted effort to exclude marginal groups who might threaten the "quality of life" in neighbourhoods and public places (MacLeod 2002:617). The people who were evicted formed the wellspring of urban movements in cities around the world (Sugranyes and Mathivet 2011). At this stage, interventionist urban agendas and state entrepreneurialism are likely to be found not only in developing countries but also in advanced economies (Swyngedouw 1996). The associated urban policies are seen as means to reconcile the pursuit of competitiveness with the provision of collective goods in an effort to ensure social cohesion while pacifying the opponents of competition. In this era, "a dramatic intensification of coercive and disciplinary forms of state intervention" (Peck et al., 2009) occurred to cope with the effects of the commodification of urban land and its consequences (Tasan-Kok 2011). New ways to moderate urban contention and deliberation (Silver et al., 2010) were then introduced. The main motivation was to neutralise dissent through co-optation. One way was to sponsor entrepreneurial interventions, whereby the state acts as a "speculative investor" in a coalition of private-sector stakeholders (Davidson and McNeil 2011). City branding and investment in large-scale infrastructure, waterfront redevelopment, and other large-scale urban projects are well known elements of the entrepreneurial ethos (Jou et al., 2011).

Strong state intervention in urban and economic development used to be characteristic of developmental states in the newly industrialised economies of Asia (Douglass 1994). Indeed, authoritarian intervention is still a "new post-crisis political instrument". In this context, authoritarian state intervention in urban development means a top-down interference of state agencies in urban development practices. By so doing, the state gives certain groups special treatment to control the social response. In the same vein, urban regulations and practices of the state agencies have become instruments to suppress dissatisfaction.

Both forms of intervention (authoritarian and entrepreneurial) in urban practices and projects have become commonplace in neoliberalising cities, where they are used to suppress public reaction. According to Zukin (1995:28), urban projects that offer a new quality of life and new consumer habits are designated to play the role of pacifying the potential reactions/urban movements-in her words, "pacification by cappuccino". As Harvey (2008) pointed out, there is nothing new about the repression of political movements via urban plans and policies. Such policies constitute indirect means of pacification, which is experienced not only in the Western world but in the developing world as well. There are other means used to suppress urban movements, where the regulations on property markets serve as compensation mechanisms (Sugranyes and Mathivet 2011).

\section{The Distinctive Character of Urban Movements and Government Responses in Turkey}

The experience of Turkey, as an example of urban movements and state response to them, is similar, though with some differences, to the first and second types of state 
response defined above (collective consumption/clientelism and new entrepreneurialism). However, we argue that the literature on the third type (new authoritarianism) is far from adequate to understand the last decade in Turkey. Therefore, this section puts more emphasis on the transforming nature of neoliberalism, its urban agenda, and the new authoritarianism experienced in the last decade in Turkey. This special attention derives from the change in the way the state deals with economic and social problems, and also from its attitude towards urban issues following the financial crisis of 1999-2001.

In order to discuss urban movements and the state response in the period following 2001 crisis, we first evaluated new urban policies and practices as well as changes in the legislation from 1990 to 2011 in Turkey (Eraydin and Altay 2011). Second, the projects initiated by local and central government departments in Istanbul have been identified in collaboration with the Planning Department of Istanbul Metropolitan Municipality; the projects have been evaluated with the help of field surveys in the major transformation zones; and a questionnaire survey has been conducted in two neighbourhoods of Istanbul (Eraydin et al., 2013). Third, the state's response to the demands of different groups in the last decade has been explored through 11 in-depth interviews, ${ }^{4}$ which were conducted with officials of local and central governments and NGOs in Istanbul and Ankara between 2011 and 2012. Furthermore, we had access to interviews carried out by Özdemir (2011) with both the local activists and residents in the Gülsuyu-Gülensu neighbourhood, where there is strong resistance to current urban projects and plans, which helped us to understand the views of the people directly involved in urban mobilisations. Finally, discourses in research and policy reports, media resources, and communications of an e-mail group that was formed by activists, residents, and professionals from different movements after the "Urban Movements Forum" (held in Istanbul on 26-27 June 2010) from 2010 to 2011 (Özdemir and Eraydin 2012) were also analysed. On the basis of these research activities, the main characteristics of the three types of state response experienced in Turkey in comparison to the general trends defined in the second section are summarised below.

The Turkish experience of clientelist urban policies as a response to urban social movements in the form of collective mobilisations for shelter and urban infrastructure from the early 1960 s through the late 1970 s resembles that of many developing countries. Corresponding to a Keynesian welfare state model, Turkey pursued rapid economic growth, administrative modernisation, and the efficient delivery of welfare services (Eraydin 2008). However, as in other peripheral countries, such ambitious goals were hard to achieve. The economic base was not ready for the transformation; in particular, it could not meet the growing need for shelter due to the massive rural-to-urban migration flows (Tekeli and Erder 1978). Therefore, the migrants had to find their own way in the big cities. The squatter settlements (gecekondu) provided migrants with a buffer in the absence of basic public services and housing (Şenyapılı 1978) but were also contested sites where socio-spatial power relations were negotiated and collective actions were organised. The main aim of participants in the emerging mobilisations was to secure material support for their neighbourhoods (the delivery of public infrastructure, transport services, deeds to the land they occupied, etc.). In that sense too, Turkey was similar to many developing countries (see Erder 1996, 1997; Öncü, 1988). 
In general, gecekondu areas became an arena where socio-spatial power relations are contested and where compromises are negotiated and regulated. Mutual expectations of benefits (for gecekondu neighbourhoods to have legal status and for politicians to gain votes) increased populism in urban politics during those years. Although gecekondu residents came from a variety of cultural and ethnic backgrounds, they showed a great deal of unity when taking their demands to local politicians. To defuse the rising tension, the government made several exemptions for gecekondu settlements in the existing planning and property legislation. The "demand-making" process (Cornelius 1975) and clientelism became an integral part of relations between the state and the urban poor. The state's acceptance of patron-client relations was a big step towards legitimising the informal development of land and enabled the migrants to survive in the major urban areas. In general, clientelism served the Turkish state as an effective tool to pacify disadvantaged groups until the economic crisis of the late 1970s.

Similar to the experience of the countries mentioned earlier, the 1970s crisis defined a shift from protectionist developmental to liberal and export-oriented economic regime. The 1980s became a turning point in economic policy with an increasing reliance on market forces. Major structural changes in the political economy paved the way for entrepreneurialism in urban politics. The state's response to urban social movements in this period has characteristics resembling the second type of state response to urban movements set forth above. They were distinguished by participatory governance approaches of central governments to institutional restructuring and re-regulation on property markets. The way these policies had been put into practice, however, was quite indistinct and modest, due to the problems related to the gecekondu areas and the populist tradition for getting political support from these disadvantaged groups.

The 1980s were marked by far-reaching political and economic changes; the transformative policies led to the neoliberalisation of the economy. In this period, the government tried to garner support from diverse groups, including those negatively affected by the new economic policies as well as the discontented citizens of earlier periods. One way it attempted to consolidate its basis was by offering opportunities within the property regime to members of various income classes. The first step was urban reform, which entailed re-institutionalisation of some state functions and the devolution of others to municipalities. The Local Administration Reform was rather modest; still, it extended the rights and responsibilities of municipalities and increased their financial resources. Especially the law on the Greater City Municipalities (No 3030, 1984) extended municipal jurisdictions and powers. While municipalities gained the authority to "plan" with the enactment of the Planning Law (No 3194) in 1985, the Law on Greater City Municipalities (No 3030) defined the rights of Greater Cities, including planning. However, relations between the state and the market as well as between central and local government were not clearly articulated in this period. The state was trying to decentralise its administrative structure, deregulate the economy and refrain from economic interventionism. Yet it had an interest in using the urban land and property market as a buffer and in manipulating urban practices to gain support from different groups. Taking a populist approach, the government passed a law on mass housing 
(No 2985, 1984) and on that basis initiated several housing projects in an effort to quell protest against the state's new economic policies. These projects did not provide housing for poor gecekondu dwellers but rather for middle-income groups. Therefore, reaching out to the disadvantaged, who were mostly living in gecekondu settlements, the government approved legislation to regularise illegally built housing. The state was simply using urban land as a tool to redistribute wealth without having to incur any immediate burden in costs or budgets. In that regard, the new policy was quite successful. It also marked a change in the nature of urban movements by weakening their grassroots basis.

The state's response to urban movements changed substantially after the 1999-2001 economic recession. This marks a second stage of change in post-war urban politics. It is characterised not only by increasing government interventions and authoritarian urban practices but also by how these policies are used to empower the groups now backing the socio-political transformation project of the government. The authoritarian policies towards any groups criticising ongoing urban practices intensified the divisions within society between those who want no intervention in their urban lifestyles and citizenship rights versus those who support the re-engineering of conservative value systems.

The year 2001 was a turning point; the financial crisis that hit the Turkish economy was followed by important changes in the public finance and banking system. Earlier attempts to instil market-based and export-oriented growth practices were seen as a model for the future. Turkey's economic policies were geared to creating a resilient financial system while supporting further integration in global markets. This policy was sustained after 2002, when the conservative centre-right AKP (Justice and Development Party) won the elections. The new government needed high rates of economic growth to legitimise the socio-political and institutional change it was striving for: re-engineering the conservative value systems in society and in the state apparatus, consistent with its strong religious rhetoric and explicit Islamist roots. The party has been acutely aware of the importance of the urban land and property market as a source of financing for economic growth. Support for urban areas could serve a dual purpose: first, to attract global economic functions and stimulate the influx of foreign investment and globally circulating capital; and second, to induce construction activities in the form of housing, offices, and infrastructure. The construction sector has been very effectual in accelerating economic growth since the early 1980s in Turkey.

The new government, however, was not confident that the market dynamics would be able to keep up the momentum of growth in urban areas. It recognised the obstacles: the limited availability of urban land; and difficulties of renewal and reconstruction in the built-up areas due to complex ownership patterns. Therefore, instead of relying on market dynamics, the government decided to take a more active role. It changed the legislation to facilitate reconstruction in built-up areas, and it assigned special rights and responsibilities to several central state departments.

Over the last decade, urban legislation has changed very frequently, showing that regulations can be easily adapted to suit the government's agenda. In the early 2000s, several laws were enacted ${ }^{5}$ to support the earlier decentralisation trend, all assigning new roles to municipalities. ${ }^{6}$ However, soon after enactment, even the 
following year, they were amended several times (Duyguluer 2006). Planning rights (usually for core areas in metropolitan cities) were transferred from municipalities to a range of central government bodies: the Ministry of Construction; the Ministry of Industry and Trade; the Ministry of Tourism and Culture; the Ministry of Environment; the State Railways Authority; and the Housing Development Administration (TOKI). Municipalities also had to cede their right to initiate new projects to central government agencies such as TOKI. The rights and responsibilities of TOKI, which was established to deliver affordable housing, have been extended over the past decade, making it the most empowered state department. TOKI gained the rights to plan and develop new housing estates and engage in construction activities as an entrepreneur. It initiated various types of transformation projects ${ }^{7}$ (regeneration, gentrification, renewal, and clearance) to stimulate construction activities. Not only were these projects vital to economic growth but they also stimulated market-state partnerships, thereby creating a new entrepreneurial group (property developers). The new legislation puts the implementation of urban regeneration projects in the hands of central government from the beginning (land development and planning) to the end (property development and redistribution of property rights). The purpose was to retain control over public property, trade parcels on the free market, and reallocate urban land that belonged to different people. The amendments to the urban legislative framework reflect the increasing interest of the state in being able to "use" the city as a tool to generate financial resources for central government and redistribute the wealth from certain groups to others (Eraydin 2011a).

In view of the rising value of land and property, some of these projects envisioned the transformation of dilapidated historic areas within or nearby the city centres, where poor and marginal groups were living. In most cases, these run-down areas were to be transformed into spaces for consumption and international capital accumulation or for tourism, but without much concern about how these changes would affect the inhabitants. Moreover, the local and central governments came to see gecekondu neighbourhoods in the central city as a source of land supply and locus of transformation projects (Kurtuluş 2006; Türkmen 2011). These projects have had a highly negative impact on those whose livelihood came from the city centre (Enlil 2003). For the developers, in contrast, they generated exceptional advantages; the developers, in turn, provided electoral and financial support for the current government. These dynamics nurtured a new entrepreneurial group that maintained close relations with the ruling party.

Some low- and middle-income groups, particularly the early immigrants, had an opportunity to make a very large profit on these projects. Others, however, like new migrants or certain religious or ethnic groups, were not so lucky. For instance, the Roma people were displaced by an urban renewal project (Sulukule). Some special conditions were introduced for disadvantaged groups who owned a gecekondu (specifically for those with a deed); in order to suppress their dissatisfaction, they were offered new apartment units. If they want to buy housing units in their neighbourhood, they have to pay the price difference between new housing units and their own property or move to new housing units built by the TOKI far from the city. However, for those without a regular job, even the easy credit terms were out of reach. Besides, settling far from the city centre had negatively affected their 
job opportunities. Therefore, most of these people subsequently left the houses offered by TOKI and came to live as tenants in areas close to their previous neighbourhoods (Schlebusch 2008; Türkün 2011). In fact, these initiatives gave rise to "deprived" groups who felt even more marginalised.

Besides these authoritarian interventions, there was an escalation of state entrepreneurialism in some metropolitan areas. Over the past decade, these have taken various forms: eg privatisation of state land to develop large-scale commercial projects; gentrification; mega-projects that have negatively affected the existing urban fabric, the environment and the landscape. These interventions have become showcases of state power, as all were decided on without getting any feedback from interested parties or urban residents.

\section{Decoding Relations Between Urban Policies, Urban Movements, and State Response}

The urban practices of the state are clearly the result of new coalitions. The government has allied itself with the emerging conservative elites, ${ }^{8}$ lower-middle classes, disaffected segments of the working class, and the "new liberal intellectuals" backed by global finance capital. Over the past decade, two types of urban movements have become prominent in Turkey. The first group of movements was mainly initiated by the discontented ${ }^{9}$ people who were not members of the new urban-political coalition. The elitist movements run by NGOs, professionals, and local activists have different political orientations and value systems than the existing government. These movements differ from the political and self-interest mobilisations initiated by the second group (the deprived) that was subject to the negative effects of urban practices. However, recent experience (May 2013 Taksim Gezi Park protests) shows how easily some of the protesters, whose protests are called "chapuling", ${ }^{10}$ can come together.

The elitist movements are opposed to the current urban practice and projects. They reject the treatment of urban land as a commodity by central and local government. They also reject the commercial projects initiated by central government. These movements were mainly started by voluntary associations and NGOs such as the Union of Chambers of Architects and Engineers. This body has been the voice of those who oppose the commodification of urban land, especially in the built-up areas that had formerly belonged to the public, and the loss of urban values and assets. Such losses vary from individual projects-such as a historic movie-house (Emek Sineması) slated to be turned into a shopping mall, or a skyscraper (Gökkafes) within the historic area that disrupts the skyline of Istanbul (Günay 2005)-to developments at the neighbourhood or even the urban scale. The infrastructure projects such as the third bridge over the Bosphorus in Istanbul also provoked urban mobilisation by groups whose concerns were limited to environmental and ecological threats and projects (Yalçıntan and Çavuşoğlu 2009).

The self-interest movements were initiated by the government's urban regeneration programme and targeted property rights (Kuyucu and Ünsal 2010; Lovering and Türkmen 2011; Türkmen 2011; Türkün 2011). These movements were initiated by deprived groups, particularly to stop demolitions and evictions in 
gecekondu and dilapidated historic neighbourhoods in metropolitan cities like Istanbul and Ankara. The residents of these areas mounted the most active resistance, as it was they who bore the brunt of the clearance (Türkün 2011) while having no chance to profit from rising urban land values (Erder 1997).

The increasing value of urban land in their neighbourhoods, along with the low likelihood of benefiting from these regeneration projects, induced some of the smaller landowners in gecekondu settlements to band together. They formed nonprofit organisations to negotiate their interests, usually with the help of activists, to improve their property rights or to raise the expropriation value. They chose to negotiate rather than to embark on a broader collective action for their right to the city (Özdemir and Eraydin 2012; Schlebusch 2008). These mobilisations should be seen as an expression of frustration among certain groups with the state's authoritarian practices. Lovering and Türkmen (2011) found more capacity for mobilisation in neighbourhoods dominated by left-wing groups, implying that the movements were not necessarily grounded in self-interest. In areas where movements had been initiated by the early gecekondu residents, mobilisation had been replaced by new forms of dissent. The latter entailed protest against the political system and demanded for democratic rights, including rights to express group identity. Some of these mobilisations did not have an urban agenda.

Clearly, the current Turkish government intends to assert its authority to implement its urban agenda. Some of the responses are characteristic of a strong centralist state. Yet others may be characterised as coercive and authoritarian for showing little if any concern with the demands of the discontented and deprived and for increasing the authoritarian discourse.

\section{Limited Positive Response to the Demands of the Discontented and Deprived}

The recent changes in urban legislation and the ongoing projects have heightened resentment among professionals, activists, and elites. At the beginning of the 2000s, new platforms were created to dispel resentment about how urban space had been shaped. Although the government was initially open to criticism, state agents are no longer willing to negotiate. Instead, the state prefers to promote the contested projects through the mass media. Mobilisations of discontented groups, especially the elite movements opposing specific government projects, were ignored by the state (ie Gökkafes-a skyscraper within the historic area-was built; Emek Sineması-a historic movie-house-was recently demolished despite enormous public outcry). Instead, the state tries to quell dissent by organising international events as part of their entrepreneurial agenda. Thereby, the state seizes every opportunity to bring new infrastructure and other facilities into metropolitan areas in order to earn the backing of the liberal elites. Any resistance to these projects, however, has been perceived by the government as a challenge to state authority. The central government has firmly rejected the demands of academics, artists, intellectuals, NGOs, and the semi-public organisations formed by occupational groups. The people's resistance to certain projects could not alter the state's 
policies, so some disputes were taken to the courts. Legal adjudication became the last resort to voice contentions and resolve disputes (Günay 2005).

The state's response to the self-interest mobilisations and claims of the deprived was not as clear-cut as its response to the protests of the discontented. As noted earlier, urban regeneration projects opened up business sites and residential areas to new affluent groups. Meanwhile, the gecekondu owners with title to their land also derived some advantage from the process. In that light, the state has promoted these projects as opportunities for some of the deprived groups to build up their resources. Yet not all groups stand to gain from certain projects. The "urgent expropriation" right given to TOKI by Law 5366 placed several restrictions on the rights of people who already held a deed. This law presents the owners with three options: to sell their property at the designated price to TOKI; to pay an additional amount of money to purchase one of the luxurious housing units built on their land by using the long-term credit system; or to accept one of the apartment units built by TOKI somewhere else, usually in a peripheral area, by taking up a lower amount of credit (Türkün 2011).

Tenants of the regeneration project areas, being post-1990s migrants, were usually offered either no compensation or an apartment with low payments on the outskirts of the Istanbul Metropolitan Area. Rarely was the offer negotiable; whoever declined to accept it would have to leave the area. But finding a new place to live became very difficult due to rising rents. Those who did accept the deal not only had to repay the loan but also had to pay for heating, services, and so forth, which absorbed a high share of their income. The change of location also led to loss of jobs. The fact is that most people living in inner-city gecekondu settlements or those living in dilapidated historic areas were working in the kind of marginal jobs that are only available in the urban core. As shown by a study on Bezirganbahçe in Istanbul, $54.4 \%$ of these displaced people lost their jobs and $31.6 \%$ had to change their place of work (Türkün 2011). However, due to conflicting interests between tenants and titleholders, the residents could not negotiate with the TOKI or private developers as a unified group. Owners tended to go along with the proposals, since the new projects would offer them some financial advantages, even though they would lose their former networks.

\section{Increasing Numbers of Authoritarian Practices and Discourse}

As the Turkish case demonstrates, not only has the state been upholding the neoliberal agenda, but that agenda has allowed the state to empower itself, buttressed by legal and institutional changes. In a situation where the democratic principles are not well established, authoritarian practices can spread quite quickly, nurturing an authoritarian attitude towards urban movements as exemplified by the excessive use of police power against the demonstrators of Taksim Gezi Park resistance movement in May 2013.

The present administration is trying to shield the state from any kind of activism and social mobilisation, either by introducing populist policies or by using force to quell demonstrations. In that sense, "punitive paternalism" as defined by 
Wacquant (2012) seems to fit the Turkish situation, where the state is becoming a less democratic entity. The AKP administration's aggressive response to any form of protest and social mobilisation (heightened police surveillance, arrest of journalists, and use of physical force to suppress activism and protest) is discouraging an organised social response by instilling fear in society.

There is ample evidence to support this argument. In the current decade, government representatives, in line with the national and local bureaucracy, have engaged in an increasingly exclusionary discourse. Their stance has been supported by the mainstream media and the newspapers, which have adopted an uncritical attitude towards the government. For instance, the gecekondu residents are now described as occupiers, and a gecekondu is now represented as a ghetto. The earlier tolerance of people living in these areas has dissipated. Formerly perceived as the outcome of an inadequate supply of housing for the urban poor, these settlements are now cast in a negative light: as "areas against plans, which spread over the cities like a tumour". When reporting the problems of these areas, the textual analysis including research and policy reports and media resources shows that they carried headlines emphasising the increasing attractivity of Istanbul, such as "Istanbul became the new star of the international property market" among similar other claims. The shift in the discourse coincides with the state's realisation that profit stands to be made from the commercialisation of urban space (Eraydin 2011b). Some of the country's most powerful individuals have a personal stake in these projects, having initiated many such developments. They justify their political correctness by pointing to the expected benefits that ordinary people stand to reap from the growing bubble on the property market.

It is apparent that state actors have adopted a new role in Turkey; they have begun to dictate what kind of transformations will have to take place in urban areas. This is the emerging face of urban neoliberal development. The policies that made the direct transfer of property rights possible, along with other support schemes based on traditional religion-based organisations, have become very important. These policies allow the state to suppress the people's reactions to the negative consequences of brutal neoliberal urban practices. As shown earlier, the state introduced some measures to compensate the loss of some groups and tried to suppress the movements by providing certain advantages to the poor.

\section{Concluding Remarks}

Neoliberalism is not only an economic project. It is also a political project (Wacquant 2012), which differs substantially among geographical contexts and related socio-political cultures, thereby producing variegated forms of institutional governance and capital accumulation. As global evidence shows, economic liberalism does not have to coincide with political liberalism (Künkel and Mayer 2012). A neoliberal economic agenda can be adopted in different types of statehood-from dictatorships and military governments to democratic regimes-creating different neoliberalisms around the world (Hilgers 2012). In fact, the neoliberal character is contingent upon the national setting (Moran 2002). But, as we argue in this paper, the agenda could also entail transforming society in the direction of less tolerance of 
diversity and alternative ideas and lifestyles. The responses of the state to these urban movements reveal the essence of the neoliberal regime and its institutional governance. It was the aim of this article to gain an understanding of the dynamics of urban governance by examining mobilisations against urban policies and practices and the response of the state to them. The Turkish case, enveloped in some reflections on Istanbul, has enabled us to discuss several aspects of the relations between the state and the market and the state and citizens over the past decade.

In this paper, we identified the crisis of 1999-2001 as the turning point toward neoliberalisation in Turkey. The crisis led not only to a change in government in 2002 but also marked a change in the state-market-citizens relation. We argue that with the help of urban practices, the state embarked on a new political project. It has become the main actor in urban practice by forming different coalitions to achieve and legitimise a socio-political transformation. This project is an effort to reassert conservative value systems, increase religious practices, and encourage democratisation in certain fields but authoritarian attitudes in others. But a critique of that project lies beyond the scope of this paper. However, it is clear that a political project to initiate a new socio-political order and advocate a conservative social agenda necessitates a strong state. In order to manipulate the growth process, the government has been changing its position abruptly, shifting from decentralisation to centralisation, providing certain rights to municipalities and giving some back to central government. It resembles the authoritarian state and unregulated market tendencies seen in several Asian countries, notably China (Ong, 2006), but also in the Middle East, North Africa and Latin America.

We also discussed the importance of the urban agenda and partnerships between the state, the market and certain citizens. Drawing these parties into the fray is the key to reaching several targets: high rates of economic growth; attracting foreign capital; and building support for political power. Urban land and property market policies have been widely used to favour certain groups and penalise others, as noted by Wacquant (2012). Under AKP rule, the new coalitions consist of the lower-middle classes, disaffected segments of the working class, and the new socially conservative, economically liberal intellectuals. The elites of earlier decades, disadvantaged groups, and minorities are increasingly excluded and thus less able to get involved in decision-making on current urban transformations. In the new urban coalitions, global finance has a special place. The capital available in the Gulf countries has been vital to the government in its pursuit of high growth rates in an effort to legitimise its neo-conservative policies. In this context, we discussed the increasing dominance of the "interventionist" regime of urban regulation with "authoritarian" and "entrepreneurial" aspirations (Lovering and Evren 2011), emphasising the changes in urban institutions via amendments to existing legislation.

The commodification of urban land by centralising urban policies and practice, thereby excluding certain groups, has mobilised the deprived groups but also the intellectuals and people with alternative political views. The demands of these groups and their protests are not well received by the government. Rather, the government sees them as obstacles to the overall project of economic development and as threats to their political power. As Abu-Lughod (1990:42) notes, "where there is resistance there is also power". The state has countered the resentment 
and the opposition to its interventions in various ways. Traditional populist policies had been used by the central government to dispel certain mobilisations. If there was an inescapable conflict between the interests of large capital and the urban poor, the latter did not usually get priority. The whole process is strongly reminiscent of scenes we have observed in many developing countries (Zunino 2006).

Overall, the Turkish case shows that contemporary urban governance is more than "the growing power of capital and the increasing inadequacy of liberal-democratic political structures as a means to check that power" (Purcell 2002). The state becomes the main actor, manipulating the whole process, trying to find ways to suppress resistance or mobilisations against its urban agenda, using the urban property market as a machine for growth. This new stage of neoliberalisation of Turkey-in which the state takes stern policy measures against the urban poor when there are conflicting interests and shows hostility toward the intellectuals who express negative feelings about the contemporary urban practices-necessitates further study to understand the implications for social cohesion and unity.

\section{Endnotes}

1 In May 2013 the resistance against the plan to destroy a park (Taksim Gezi Parki) in Istanbul to create a shopping mall and the excessive police force used against protestors has initiated massive social response all around the country, turning the movement against authoritarian AKP government and the Prime Minister Recep Tayyip Erdogan.

2 This group comprises mostly secularist people with better education and high social or economic status, sometimes called "intelligentsia bureaucracy".

3 The original concept was conceived by Marx.

${ }^{4}$ Of the 11 interviews, three were conducted with local government officials; two with urban planners from Maltepe District Municipality, and the head of the planning department of Istanbul Metropolitan Municipality; two with bureaucrats of the central government (one from the Ministry of Environment and Urbanisation, the other from the Ministry of Development). Moreover, the Executive Secretary of the Chamber of Architects Istanbul Branch, who is an academic and active supporter of the urban movements as a volunteer, and three research team leaders working at gecekondu transformation areas also participated in the interviews.

5 The Law on Special Province Administrations (5197); the Law of Municipality (5215); the Metropolitan Municipality Law (5216); the Law on Amending the Cultural and Natural Assets Conservation Law (5226); the Law on Special Province Administrations (5197) on the organisation, administration, functioning, organs, roles and responsibilities of special provincial administrations; the Law of Municipality (5215) defining the organisation, roles and responsibilities of municipalities; the Metropolitan Municipality Law (5216) redefining the functions and organisation of Metropolitan Municipalities; and the Law on Amending the Cultural and Natural Assets Conservation Law and Several Laws (5226) that identify the role of municipalities and other new councils on conservation of cultural and natural heritage.

6 The Law on Special Province Administrations (5197) on the organisation, administration, functioning, organs, roles and responsibilities of special provincial administrations; the Law of Municipality (5215) defining the organisation, roles and responsibilities of 
municipalities; the Metropolitan Municipality Law (5216) redefining the functions and organisation of Metropolitan Municipalities; and the Law on Amending the Cultural and Natural Assets Conservation Law and Several Laws (5226) that identify the role of municipalities and other new councils on conservation of cultural and natural heritage.

7 Two pieces of legislation in particular provide exceptional rights to TOKI. One is the Law on Transformation of Areas with Disaster Risk: No 6306 (2012). The other is the Law (No 5366) passed in 2005 on Redevelopment and Rehabilitation of Dilapidated Historical Areas.

8 Conservative elites in Turkey constitute a "new social group"; that is, they form a religiously more conservative elite, perhaps best described as an amalgam of "Islamic and modern".

9 The definition of deprived in this paper is slightly different than that of Marcuse (see Brenner, Marcuse and Mayer 2009:181). Marcuse defines discontented as those who were disrespected, treated unequally because of sexual, political and religious orientation, censored in speech, writing, research and artistic expression, forced into alienating jobs or otherwise constrained in their capacity to explore the possibilities of life.

10 This is a very new term created by the protestors of May 2013 in Taksim, based on the term used by the Prime Minister who called protestors "çapulcu" (looter, pillager, plunderer).

\section{References}

Abu-Lughod L (1990) The romance of resistance: Tracing transformations of power through Bedouin women. American Ethnologist 17(1):41-55

Baptista I (2012) Practices of exception in urban governance: Reconfiguring power inside the state. Urban Studies 50(1):39-54

Blakeley G (2010) Governing ourselves: Citizen participation and governance in Barcelona and Manchester. International Journal of Urban and Regional Research 34(1):130-145

Brenner N, Peck J and Theodore N (2010) Variegated neoliberalization: Geographies, modalities, pathways. Global Networks 10:182-222

Castells M (1977) The Urban Question. London: Arnold

Castells M (1983) The City and the Grassroots. London: Arnold

Cornelius W A (1975) Politics and the Migrant Poor in Mexico City. Stanford: Stanford University Press

Davidson M and McNeil D (2011) The redevelopment of Olympic sites: Examining the legacy of Sydney Olympic Park. Urban Studies 49(8):1625-1641

Douglas W R (2003) City: Urbanism and its End. New Haven: Yale University Press

Douglass M (1994) The "developmental state" and the newly industrialised economies of Asia. Environment and Planning A 26(4):543-566

Dumenil G and Levy D (2009) The nature and contradictions of neoliberalism. Socialist Register 38:44-71

Duyguluer F (2006) Imar Mevzuatının Kayıpları, Planlama. TMMOB Sehir Plancıları Odası Dergisi 20(4):27-37

Enlil Z (2003) 1980 sonrasında İstanbul'da toplumsal ayrışmanın mekansal izdüșümleri. Mimarist 3(8):84-89

Eraydin A (2008) The impact of globalisation on different social groups: Competitiveness, social cohesion, and spatial segregation in Istanbul. Urban Studies 45(8):1663-1691

Eraydin A (2011a) The outcome of neoliberal policies on Istanbul metropolitan area: What neoliberal planning stands for? In T Tasan-Kok and G Beaten (eds) Contradictions of Neoliberal Planning: Cities, Policies, and Politics (pp 61-78). Dordrecht: Springer

Eraydin A (2011b) Changing Istanbul city region dynamics: Re-regulations to challenge the consequences of uneven development development and inequality. European Planning Studies 19(5):813-837 
Eraydin A and Altay D (2011) “Kentsel Arsa Üretimini Yönlendiren Yeni Düzenlemeler ve Yönetişim Biçimleri: Eleștirel Değerlendirme”. Paper presented at Konut Sempozyumu, TMMOB Mimarlar Odası İstanbul Büyükkent Șubesi, Istanbul

Eraydin A, Türel A and Altay D (2013) The evaluation of different processes of spatial development from a resilience perspective in Istanbul. In A Eraydin and T Tasan-Kok (eds) Resilience Thinking in Urban Planning (pp 179-196). Dordrecht: Springer

Erder S (1996) İstanbul'a Bir Kent Kondu: Ümraniye. İstanbul: İletişim Yayınları

Erder S (1997) Kentsel Gerilim. Ankara: Uğur Mumcu Araştırmacı Gazetecilik Vakfı

Feliz M (2012) Neo-developmentalism: Beyond neoliberalism? Capitalist crisis and Argentina's development since the 1990s. Historical Materialism 20(2):1-19

Günay B (2005) Skyframe (Gökkafes) in Istanbul: An ontological assessment. Journal of Urban Design 10(1):111-132

Harvey D (2003) The right to the city. International Journal of Urban and Regional Research 27(4):939-941

Harvey D (2008) The right to the city. New Left Review 53(4):23-40

Hickey S and Bracking S (2005) Exploring the politics of chronic poverty: From representation to a politics of justice? World Development 33(6):851-865

Hilgers M (2012) The historicity of the neoliberal state. Social Anthropology 20(1):80-94

Holm A and Kuhn A (2011) Squatting and urban renewal: The interaction of squatter movements and strategies of urban restructuring in Berlin. International Journal of Urban and Regional Research 35(3):644-658

Jessop B (2002) Liberalism, neoliberalism, and urban governance: A state-theoretical perspective. Antipode 34(3):452-472

Jou S J, Hansen A L and Wu H L (2011) Accumulation by dispossession and neoliberal urban planning: "Landing" the mega-projects in Taipei. In T Tasan-Kok and G Baeten (eds) Contradictions of Neoliberal Planning: Cities, Policies, and Politics (pp 151-173). Dordrecht: Springer

Kratke S (1992) Urban land rent and real estate markets in the process of social restructuring: The case of Germany. Environment and Planning D: Society and Space 10:245-264

Kratke S (2004) City of talents? Berlin's regional economy, socio-spatial fabric, and worst practice urban governance. International Journal of Urban and Regional Research 28(1): 511-529

Künkel J and Mayer M (2012) Neoliberal Urbanism and its Contestations: Crossing Theoretical Boundaries. Basingstoke: Palgrave

Kurtulus H (2006) Kentsel donusume modern kent mitinin cokusu cercevesinden bakmak. Planlama Dergisi 2006(2):7-11

Kuyucu T and Unsal O (2010) Urban transformation as state-led property transfer: An analysis of two cases of urban renewal in Istanbul. Urban Studies 47(7):1479-1499

Leitner H, Sheppard E S, Sziarto K and Maringanti A (2007) Contesting urban futures: Decentring neoliberalism. In H Leitner, J Peck and E S Sheppard (eds) Contesting Neoliberalism: Urban Frontiers (pp 13-37). New York: Guilford

Leontidou L (2010) Urban social movements in "weak" civil societies: The right to the city and cosmopolitan activism in Southern Europe. Urban Studies 47(6):1179-1203

Lovering J and Evren Y (2011) Urban development and planning in Istanbul. International Planning Studies 16(1):1-4

Lovering J and Turkmen H (2011) Bulldozer neoliberalism in Istanbul: The state-led construction of property markets and the displacement of the urban poor. International Planning Studies 16(1):73-96

MacLeod G (2002) From urban entrepreneurialism to a "revanchist city"? On the spatial injustices of Glasgow's renaissance. Antipode 34(3):602-624

Mayer M (2000) Urban social movements in the era of globalisation. In P Hamel, H Lustiger-Thaler and M Mayer (eds) Urban Movements in a Globalising World (pp 141-156). London: Routledge

Mayer M (2007) Contesting the neoliberalization of urban governance. In: H Leitner, J Peck and E S Sheppard (eds) Contesting Neoliberalism: Urban Frontiers (pp 90-115). New York: The Guilford Press

Mayer M (2009) The "right to the city" in the context of shifting mottos of urban social movements. City 13(2):362-374 
Moran M (2002) Understanding the regulatory state. British Journal of Political Science 32(2): 391-413

Öncü A (1988) The politics of the urban land market in Turkey. International Journal of Urban and Regional Research 12(1):38-64

Ong A (2006) Neoliberalism as Exception. Durham: Duke University Press

Özdemir E (2011) "Urban Space as a Product of Representations of Different Interests - The Second Report". Unpublished manuscript

Özdemir E and Eraydin A (2012) "Contesting neoliberal urbanisation: Contemporary urban movements in Istanbul". Paper presented at AESOP $26^{\text {th }}$ Annual Congress, Ankara, July

Peck J (2010) Zombie neoliberalism and the ambidextrous state. Theoretical Criminology 14(1): 104-110

Peck J and Tickell A (2002) Local modes of social regulation? Regulation theory, Thacherism, and uneven development. Geoforum 23(3):347-364

Peck J, Theodore N and Brenner N (2009) Neoliberal urbanism: Models, moments, mutations. SAIS Review XXIX(1):49-66

Piffero E (2009) What Happened to Participation? Urban Development and Authoritarian Upgrading in Cairo's Informal Neighbourhoods. Bologna: I libri di Emil

Purcell M (2002) Excavating Lefebvre: The right to the city and its urban politics of the inhabitant. Geo/ournal 58(2):99-108

Rocha S M (2012) "Democracy and foreign policy in the Southern Cone of Latin America". President Néstor Kirchner Fellowship Working Paper No 2. http://observatorylatinamerica. org/en/programs/pnk/publications-president-nestor-kirchner-fellowhip/working-papers/ 290-democracy-foreign-policy-southern-cone-latin-america (last accessed 10 July 2013)

Schlebusch S (2008) Bringing Development to Sulukule: An Anthropological Study of Gentrification, Activism and Place-Making. Istanbul: Yeditepe University Institute of Graduate Studies in Social Science

Șenyapılı T (1978) Bütünleșmemiș Kentli Nüfus Sorunu. Ankara: ODTÜ Mimarlık Fakültesi

Silver H, Scott A and Kazepov Y (2010) Participation in urban contention and deliberation. International Journal of Urban and Regional Research 34(1):115-129

Smith N (2002) New globalism, new urbanism: Gentrification as global urban strategy. Antipode 34(3):427-450

Sugranyes A and Mathivet C (2011) Cities for All: Proposals and Experiences Towards the Right to the City. Santiago: Habitat International Coalition

Swyngedouw E (1996) Reconstructing citizenship, the re-scaling of the state, and the new authoritarianism: Closing the Belgian mines. Urban Studies 33(8):1499-1521

Swyngedouw E (2010) "Post-Democratic Cities: For Whom and For What?" Paper presented to the Regional Studies Association annual conference, Budapest, May. http://regionalstudies-assoc.ac.uk/events/2010/may-pecs/papers/Swyngedouw.pdf (last accessed 20 March 2012)

Tasan-Kok T (2011) Introduction. In T Tasan-Kok and G Baeten (eds) Contradictions of Neoliberal Planning: Cities, Policies, and Politics (pp 1-20). Dordrecht: Springer

Tekeli I and Erder L (1978) In Migration as Accordance Process of Settlement Structure. Ankara: Hacettepe University Publications

Türkmen H (2011) "Debates on the right to the city in Istanbul". Paper presented to the conference The Struggle to Belong: Dealing with Diversity in $21^{\text {st }}$ Century Urban Settings, Amsterdam, July

Türkün A (2011) Urban regeneration and hegemonic power relationships. International Planning Studies 16(1):61-72

van Eijk G (2010) Exclusionary policies are not just about the "neoliberal city": A critique of theories of urban revanchism and the case of Rotterdam. International Journal of Urban and Regional Research 34(4):820-834

Wacquant L (2012) Three steps to historical anthropology of actually existing neoliberalism. Social Anthropology 20(1):66-79

Walton J (1998) Urban conflict and social movements in poor countries: Theory and evidence of collective action. International Journal of Urban and Regional Research 22(3):460-481 
Yalçıntan M and Çavuşoğlu E (2009) Kentsel dönüşümü ve kentsel muhalefeti kent hakkı üzerinden düşünmek. http://academia.edu/270770/Kentsel_Donusumu_ve_Kentsel_ Muhalefeti_Kent_Hakki_Uzerinden_Dusunmek (last accessed 3 December 2011)

Yılmaz K (2009) The emergence and rise of conservative elite in Turkey. Insight Turkey 11(2): $113-136$

Zukin S (1995) The Cultures of Cities. Oxford: Blackwell

Zunino H M (2006) Power relations in urban decision-making: Neoliberalism, 'techno-politicians', and authoritarian redevelopment in Santiago, Chile. Urban Studies 43(10):1825-1846 